\title{
Competitiveness, local production systems and global commodity chains in the music industry: entering the US market
}

Dominic Power and Daniel Hallencreutz 


\title{
Dominic Power and Daniel Hallencreutz
}

\author{
Department of Social and Economic Geography \\ Centre for Research on Innovation and Industrial Dynamics (CIND) \\ Uppsala University \\ Box 513, S-75120 Uppsala \\ Sweden \\ Tel: +46-18-4712538 Fax: +46-18-4717418 \\ dominic.power@kultgeog.uu.se
}

\section{'Competitiveness, local production systems and global commodity chains in the music industry: entering the US market'}

\section{Acknowledgements}

The authors would like to thank the Nordic Innovation Centre for their support of this project and for the participants in the wider project "Behind the Music - Profiting from Sound: A Systems Approach to the Dynamics of Nordic Music Industry" for their input. We are particularly appreciative of the members of the many companies, industry organisations and public bodies who were kind enough to give up their time to be interviewed and give us most of the information this paper is based upon. We would also like to thank the valuable comments Michael Storper, Meric Gertler, Andrew Leyshon and Anders Malmberg. 


\title{
'Competitiveness, local production systems and global commodity chains in the music industry: entering the US market'
}

\begin{abstract}
This article is based on the results of interviews with music industry actors in the USA, and several other countries, that examined the industry, distribution and retail structures controlling 'foreign' music's access to the world's largest music markets. The paper uses the US market in order to demonstrate and trace the principal channels and barriers that determine the conditions of market access for a musical product. It is shown that music distribution channels and retail environments exist in a networked commodity chain dominated by a limited set of oligopolistic global firms. The journey of a foreign musical product to market in the USA is a difficult one through a set of globally interlinked but highly fractured and localised commodity pools and channels. The paper concludes by suggesting that for firms and national industries interested in exporting to the USA understanding the workings of these links between products and consumers is vital. The implications for regional industrial and innovation policy of power over products' commercial success being 'located' largely outside the local production centre are argued to be far-reaching. In summary, the article is premised on the idea that if we are to understand success or failure in music sales and better develop regional production milieus we must first understand those who control the distribution channels and retail environments that sales are made through. In such a task a revised version of the global commodity chain perspective has much to offer researchers and policymakers alike.
\end{abstract}

Key words: music industry, economic geography, US music market. 


\section{"Competitiveness, local production systems and global commodity chains in the music industry: entering the US market"}

\section{Introduction}

Research on the music industry has long tried to understand why it is that certain places have been unusually productive crucibles for the creation of popular music (Hesmondhalgh 1996; Scott 1999a; Scott 1999b; Scott 2000b; DuNoyer 2002). Cities such as New York, Los Angeles, Nashville, London, and Liverpool have often been pointed to as accounting for a disproportionate share of super hits and artistes. It is perhaps not surprising then that explanations of success on global music markets have also tended to focus on the role of certain places in creating musical innovation and commercial success. Scott (1999a, p.1874) for instance suggests that spatial agglomerations in the music industry are important because they are not just "spatial accumulations of physical capital, but also evolving pools of human skills and aptitudes." These pools or communities of workers are, he continues, "the preserve of accumulated traditions and conventionalized sensibilities (including cultural norms as embodied, for example, in particular musical genres), and they function as potent frameworks of cultural reproduction and arenas of socialization." The message here, as in many modern agglomeration accounts (cf. Maskell et al 1998), is that spatial clustering and agglomeration seems particularly important to the development of different types of 'soft infrastructures' that are in turn crucial to success in the music business. Competitiveness then, even in highly global product markets such as music, relies on local capacities and milieus where the sharing of "conventions, common languages and rules for developing, communicating and interpreting knowledge" (Storper 1995: 206) makes for better and more competitive products.

This account of competitiveness being rooted in local milieus and knowledge creation resonates well with a growing theoretical literature in economic geography and related disciplines that stresses the importance of local capabilities for firms' (not just music firms) ability to create and sustain international competitiveness (Amin and Thrift 1994; Dicken 1992). Indeed during the 1990s a veritable flood of literature and new approaches to economic geography all emphasized the centrality of the local in the determination of competitiveness: for example, innovative milieus (Camagni 1991, Maillat 1991, 1995), untraded interdependencies (Storper 1995), industrial clusters (Porter 1990, 1998, Sölvell et al. 1991), regional innovation systems (Cooke and Morgan 1998), industrial systems (Saxenian 1994), industrial networks (Håkansson 1987), and Neo Marshallian nodes (Amin and Thrift 1992). The popularity of such approaches and theories have meant that whether we are talking about biotechnology or music it is now largely assumed that strong products built in strong knowledge-based centers are what determines long term success (Malmberg and Power 2005 Forthcoming).

It is undoubtedly true that due to their unique mixes of creative and productive factors certain places have been especially good at making commercially successful music. However, we find it problematic to make a further assumption that is deeply embedded in the literature on the music industry (and indeed other artistic or cultural industries: cf. Power and Scott 2004): i.e. that it is almost entirely due to the competitive, sometimes even artistic, qualities of the music produced in these places that market success is secured. Whilst the qualities of the product and its production are, of course, central to explaining competitiveness we think that there has been a 
neglect of systems of distribution, retail and market dynamics in explaining product success and market entry. As Negus (Negus 1996; Negus 1999) and others (duGay and Negus 1994; Alexander 1996) have pointed out, for consumer products like music systems of distribution and marketing cannot be neglected. This literature draws our attention to the idea that it is crucial to connect the widespread appeal of an artist (and the genre an artist is working in) with the systems of production and distribution that have put a 'global' superstar in the position to be globally popular in the first place. Thus, there may be many musical styles and artists around the world that have the potential to be universally enjoyed by large audiences. In reality though, some of these genres/artists are more likely to be prioritized by the global music industrial system than others (Negus 1996).

In contrast to the view that if you have a dynamic creative milieu it will produce music of such competitive quality that people will almost automatically want to buy it, a growing literature on the complexities and inequalities inherent in global commodity chains points out that no matter how good a product may be the conditions of access to markets are crucial in deciding a product's potential success (Gereffi 1994; Gereffi and Korzeniewicz 1994). Just as with other commodities that are potentially exportable to any number of markets across the globe, popular music products can encounter a wide range of both open and closed doors in their journey to foreign ears. Thus it is extremely important to export-oriented musicians and firms to understand the channels, entry points, and problems that are associated with getting access to their target markets.

In line with this type of understanding we argue here that in order to understand how success is achieved by certain products one cannot just look to the place of production. One must attempt to take account of both. Thus we argue here that in order to understand consumer product markets we should work from the interlinked assumptions that (a) successful products tend to be based on strong local production systems, but (b) the processes and dynamics of the selling, distribution and retail in destination markets have profound effects on products' success. It is not only then in the local 'buzz' (Storper and Venables 2002) and innovation system that competitiveness has it roots but also in 'pipelines' (Bathelt, Malmberg and Maskell 2002) and commodity chains (Gereffi, 1994). We must, in short, attempt to also include an understanding of connections and assets that lie outside the local milieu (or even cluster) and see how the production centre is linked to markets and sites of consumption. Moreover, as Gereffi argues the success of many products is more often determined by globally dispersed buyers' demands than by the way the product is produced in a local production center (Gereffi 1994; Gereffi and Korzeniewicz 1994).

Thus, the objective of this paper is not to discuss the nature of regional innovation systems /institutional thickness, etc. or the failings of 'new regionalist' and 'institutionalist' accounts to take full account of processes operating at different socio-spatial scales, inter-scalar relations or the rescaling of socio-economic processes. Nor is the objective of the paper is to examine or explain 'pipelines', commodity chains and the (territorialized) power relations within and across value chains - although we touch upon all these issues. Rather the aim is to, empirically, explore the need for more complex approaches to economic geography and for the need to further explore the relationship between localized production (and innovation) and market dynamics and commercialization. We attempt to do this by focusing on the complex relations of access and gate-keeping that structure the market for recorded music in the US. 
In the rest of the paper we examine the conditions and problems of entry foreign musical products incur in relation to the US music market. In particular, we focus on the processes and associated problems with 'breaking' and selling a foreign musical product in the USA. Above all we focus on the sale of physical media - music embedded and sold on various types of plastic: audio formats (singles, LPs, cassettes, CDs, DVD Audio, SACD, MiniDisc) and music video formats (DVD, VHS, VCD). We do not deny that the new possibilities afforded by electronic distribution of music over the internet or mobile telephony have not had a seismic effect on the music industry (Leyshon 2001; Alderman 2002; Ku 2002; Leyshon 2003; Power and Jansson 2004; Leyshon, Webb, French, Thrift and Crewe 2005) and are likely to recast the music industry even further in the future. What we do is acknowledge here that - like many other consumer products - music is still largely sold in physical formats in physical retail spaces.

The paper argues that to understand the success of musical products, particularly within the US market, the geography of its production can only ever be part of the story. Equally important to understanding musical success is the story of how music enters the distribution systems that deliver musical products to markets. The paper argues that one of the reasons that foreign content has been less successful within the US market - the largest in the world - has been due to difficulties of accessing US distribution channels. Four elements in accessing US distribution channels are singled out for treatment: the process of promoting or 'breaking' an act; the licensing and distribution system; the role of retailers; and the current restructuring of the US market's priorities.

\section{Methodology}

The results reported in the paper draw not only on extensive analysis of available academic, popular, and industry press and literature on music and the US music market but also on qualitative research undertaken by the authors. The majority of the material collected came from a series of face-to-face interviews carried out with music industry actors in New York during October 2002. Executives from all the major record companies, several of highest grossing 'independent' record companies, smaller record labels, the largest distribution firms, several of the biggest music retail chains, and New York based foreign trade promotion authorities were interviewed. Telephone and email interviews were also carried out with companies and industry organizations located outside New York: principally Los Angeles.

In the text below some of the interviewees and their firms will be named but for reasons of confidentiality many of the respondents will not be named or directly referred to. In the course of our research we were frequently presented with legally binding agreements not to specifically name sources or their employer. It may be of interest to note that when interviewing and contacting the larger firms (both the 'majors' and 'independents') all our contacts first cleared the meeting with their firm's legal department/lawyers. In several cases meetings that had been arranged were cancelled at the last minute due to 'legal advice'. Whilst legal concerns undoubtedly affected our sample we found respondents more than happy to talk at liberty once it was understood that we were not interested in company secrets and respected their concerns over confidentiality. Indeed the level of paranoia about information leaking out and being attributed signals both the level of competition in this knowledge based industry and also the importance to firms and actors of their reputations. 
Figure 1: Main areas of activity in the music industrial system

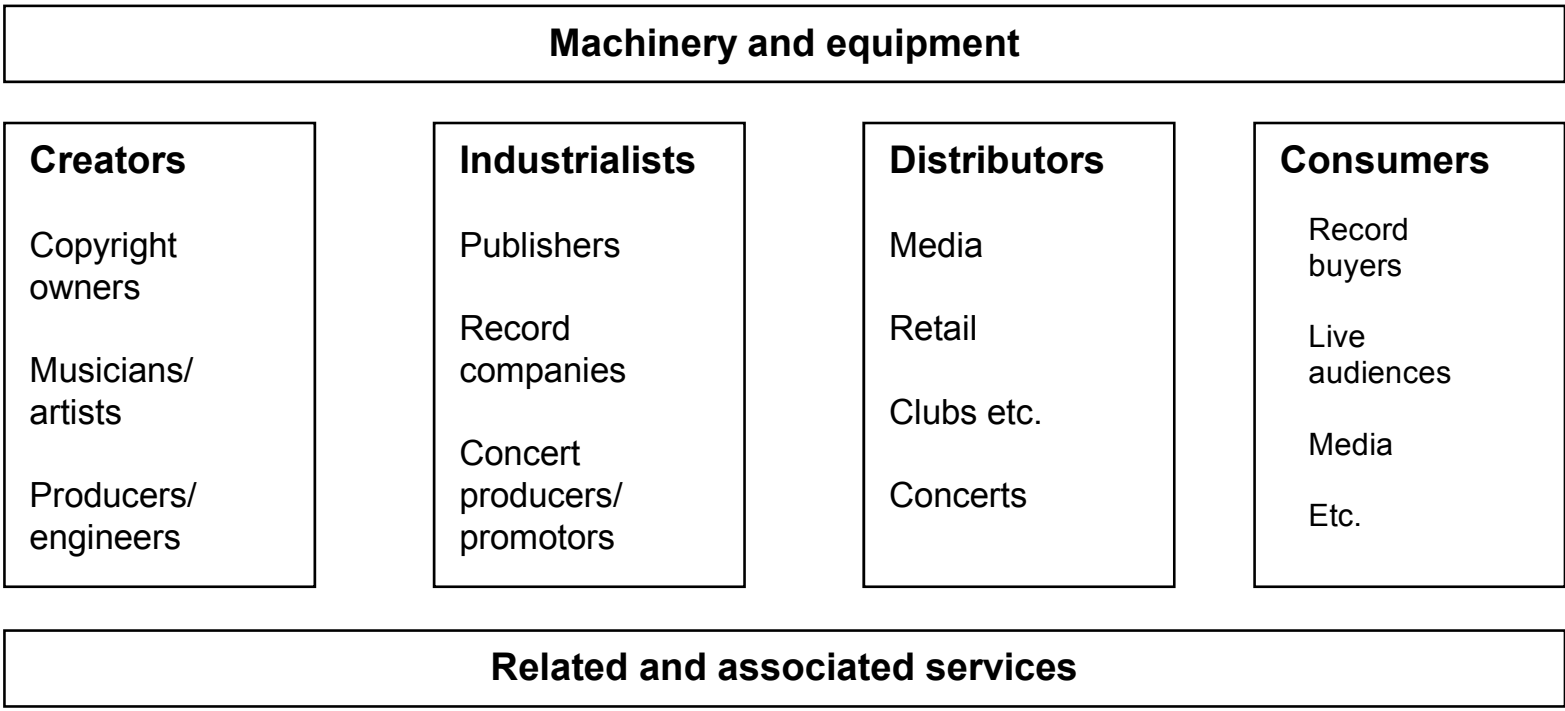

In addition to the research conducted in the US the article draws on research undertaken as part of two broader projects on the popular music industry in Sweden and the Nordic countries (cf. Hallencreutz 2002; Hallencreutz et al. 2000; 2003; 2004; Power 2003; Power \& Hallencreutz 2002; 2005; Power \& Jansson 2004). Carried out between 1999 and 2004 these two projects involved over 150 face-to-face interviews. These interviews have been complemented by numerous informal contacts and conversations with industry actors at events and industry conferences/meetings. Due to the export orientation of the Nordic music industries and the many connections and links between the US and Nordic (esp. Swedish) industries these voices from the 'outside' were an invaluable source of information on the US music market and gaining entry to it.

The interview sample for all the above was selected to represent firms (majors and independents) and organizations operating in four broad core sectors: see Figure 1. Whilst there was an attempt made to approach and cold-call interesting actors the difficulties and demands of corporate interviewing (Schoenberger 1991; Clark 1998) meant that the vast majority of our interviewees came through earlier contacts. Our sampling technique was largely based on snowballing. Whilst the snowball method involves a series of sampling problems, in this case it gave us invaluable information on the structures and conditions of access to different players and told us much about the hierarchies and networks of the industry.

\section{The music industry as an industrial production system, the global music}

\section{market and the USA}

Although the modern music industry has its roots in the early twentieth century when technological innovations (phonograms, etc.) made reproduction rather than concerts and published music the basis of the industry - its present shape and size owes much to the rising incomes and personal experimentation of young people 'youth culture' - in Europe and Northern America from the 1950s and onwards (Eliot 
1990; Firth 1992; Burnett 1996; Sadler 1997; Andersen, Kozul-Wright and KozulWright 2000). In order to meet this rising demand an industrial system has grown up that encompasses a wide range of firms and specialism.

The industrial system that has evolved around musical products involves aesthetic and industrial production which is embedded in a number of distinctive economic and culture-producing functions and intermediaries that support different phases of the production chain (Scott, 2000). The production of music is, of course, far from a series of linear activities undertaken by different atomistic firms or creators. Rather it could be seen as a number of intersecting areas - networks - where ideas and commodities are circulated amongst individuals and firms. Leyshon (2001 p 60 ) suggests that a series of interlinked networks characterize the music industry:

"first, a network of creativity, formed from the fusion of networks of composition and representation, wherein music is created through multiple acts of performance; second, a network of reproduction, which is a narrower definition of the original network of repetition, and which includes the manufacture of multiple copies of audio recordings; third, a network of distribution, as described earlier; and, fourth, a network of consumption, incorporating retail organisations."

Thus the lines between creativity, innovation, production and distribution are often very fuzzy. Actors and organizations within the industry frequently are involved in several different networks. A consistent theme within the music industry has been the existence of large global music firms - referred to as the 'majors' - that have total control over the entire value chain: from sourcing and nurturing creativity, to industrializing it, distributing it and even retailing it. After a long process of consolidation the global music business is now dominated by just four global conglomerates that together account for $74.7 \%$ of 2004 's global sales of physical music media (IFPI (International Federation of the Phonographic Industries) 2004): Vivendi-Universal; BMG-Sony Corporation; EMI Group; and AOL Time-Warner Inc.

However, it would be wrong think that the music industry is just about the majors. There is a large pool of 'independent' music companies ranging greatly in size and specialism. Some of the larger independents mimic the organizational range and scope of the majors whilst many others are small in scale or strictly focused on particular niche markets. Beyond the confines of single firms or corporations, the increasing use of project working as an organizational form within the music industry further binds together disparate actors and innovation paths. This picture is further complicated when it is remembered that there is seldom just 'music' and that different genres and sub-genres exist; with often very different consumers and allied industrial systems (Negus, 1999). Indeed throughout the history of the music industry interactions and relations between majors and independents has been key to innovation and market dynamics (Lopes 1992; Alexander 1996; Alexander 1996).

Despite the vast array of genres and industrial actors all involved in the production of music face consumer markets that are highly competitive: fickle, fashion-led consumers who have an almost limitless number of musical products and genres to choose from; competition from other entertainment products (films, magazines, games, books, etc.); the existence widespread, and according to the industry increasing, levels of piracy. Given these conditions it is not surprising that very few records actually recover their production costs and even fewer that create 
significant returns (cf. Leyshon, 2001). The risks involved and the importance of getting at the consumers in the most advantageous way possible means that music is increasingly a demand-driven marketplace where those actors nearest the end consumer have a powerful presence in determining the conditions within the industry. Media organizations (television, radio, film, magazines, new media) as well as large retailers have indeed forced 'backwards integration' onto the industry.

"Retailers now occupy an increasingly influential position within the production/consumption relations of popular music. Whereas in the past, the record companies as 'producers' or 'manufacturers' tended to exert control over the retailers through 'forward integration' and control of the product, today it is 'backward integration' from the retailer which is shifting power relations within the industry" (Du Gay and Negus (1995 p397)

Nowhere perhaps are all of these aspects of the music industry more apparent than in the USA. The US music market has long played a leading role in music industry innovation and due to its sheer size it has had a determinant effect on many of the world's other music markets. In 2000 the retail value of the global music market was worth US\$37 billion; of this the US market accounted for $38 \%$ of retail value (30\% of volume) or almost US\$14 billion (IFPI (International Federation of the Phonographic Industries) 2001). In addition to being the world's largest market the US has historically dominated the global music market by producing and exporting some of the biggest selling stars and stylistic innovations, and through this providing much of the material and record labels that dominate the global sale and distribution of music (Wallis and Malm 1984; Firth 1992; Hirsch 1992; Malm and Wallis 1992; Shapiro, Abercrombie, Lash and Lury 1992; Choi and Hilton 1995; Alexander 1996; Burnett 1996; Sadler 1997; Scott 1999a; Scott 2000b).

"To be a truly world-wide superstar is impossible without success in America." (Chris Wright, founder of Chrysalis Records: quoted in (D'Arcy and Brindley 2002))

However, despite being by far the world's largest and most influential music market it is also one of the least internationally oriented markets. In $2000,92 \%$ of sales in the US were of domestically produced products (IFPI 2001: 24). A further 3\% was classical music, leaving only $5 \%$ of the total market accounted for by repertoire of a foreign origin. With only $5 \%$ of the market accounted for by popular music produced outside the country the USA is the third least internationalized music market in the world: with only Pakistan and Egypt importing less international music (1\% of each countries market value is accounted for by foreign repertoire: IFPI 2001, p.174175).

Moreover, the sheer size of the market and combined with the fact that artistes that are successful in the US tend to become successful around the world means that for countries with export oriented music industries, such as Sweden or Ireland, expanding their share of the US market is a very attractive proposition (if not a priority). The inward looking nature of the US music market, however, makes this is a difficult goal to attain. With this in mind a study was made of what it takes to establish - or in the industry's terminology to 'break' - a musical product in the US market. 
On the basis of the research done four key themes emerged as of especial importance to the success of a musical product (be it the music of a particular act or a ready made product such as a compilation album, etc.) that is attempting to enter, or already has entered, the US music market. The rest of the paper is divided between these four aspects. Following these a concluding discussion addresses the implications of these findings for the competitiveness of foreign products entering the US market and for foreign exporters - both firms and national industries - interested in the USA.

\section{Getting it to people's ears: breaking and promoting music}

The market for music is one characterized by almost infinite choice as each year well over 10,000 new albums are released in the US alone. Both sides of the industry, the sellers and the buyers, thus operate in a world of infinite choices and thereby uncertainty. Faced what such information problems it is therefore little surprise that both consumers and the music industry rely heavily on the powers of the media to the filter and disseminate information on what is available.

Whilst there are a growing number of channels for the promotion of music music press, television stations and specialized music video station, promotional tours and performances, film, and the internet - it is radio (principally FM-radio) that remains the predominant channel for the promotion of music in the USA. All the people interviewed pointed to the playing of songs on radio as the essential ingredient for entry into the market; though they said that music featured in television adverts or Hollywood films were key exceptions. Furthermore they pointed to the fact that radio play must be intensive for the song to get onto the agendas of potential consumers: it was often said to us by industry actors that a record needed a coherent 'radio story'. Estimates of how many times a record needed to be played in order to be picked up by the public varied between those interviewed but these estimates all fell into the range of between 50 and 200 times a month on a single station. Furthermore they suggested that these 50-200 plays per month needed to be at certain peak times of the day; though these 'peak' times varied somewhat depending on the type of record and target audience.

America is a large country with a correspondingly large number of radio stations: there were 10,983 commercial radio stations in March 2001. Since changes in the regulation of radio station ownership in 1996 a period of restructuring has hit the industry. Between 1996 and $200120 \%$ of radio stations changed ownership and in general there was a $25 \%$ decrease in the number of owners (Federal Communications Commission 2001). This round of mergers and acquisitions has meant that ownership has become increasingly concentrated. For instance, one company Clear Channel Communications owns over 1000 radio stations and accounted for, in March 2001, $26 \%$ of the industry's annual revenue (Federal Communications Commission 2001). In general, it is these large radio concerns and the radio networks that are seen as the most important to record companies. It is clear that this consolidation of the industry has made stations even more eager than before to garner extra revenue sources and the record industry has long been a lucrative source.

Getting songs onto the stations' play-lists has always been a costly procedure for record companies. Historically what appeared on US radio arrived there through a system dubbed 'payola' which basically involved the bribing of radio programmers to place a song on the airwaves. Payola reached its heights in the 1950s but by the 1960s a process of legislative action started to make the direct payment of employees of 
radio stations illegal (for fuller histories of payola in the US music industry see: (Denisoff and Schurk 1986; Eliot 1990; Dannen 1991; Segrave 1994; Caves 2000). Despite the effective criminalization of payola the system can be said to live on in different forms. The principal form in which it survives is the trend since the 1980s of having independent 'promoters' working as intermediaries between the music and the radio industries. These promoters filter the music available and work out a priority list for the radio station they serve. The independent status of these promoters frees the stations from accusations of impropriety and distances the record companies from bribery charges. These promoters have managed, by various methods, to gain exclusive control of stations' play lists and are in turn hired by record companies interested in having a song on the promoters' stations. Whilst this form of payola is in retreat (Caves 2000, p292) fees for placing a song on a large station can reach US $\$ 10,000$. Record company executives we spoke to suggested that in various forms these practices were still commonplace. Tom Silverman, founder and CEO of the large independent record/entertainment company Tommy Boy Music, stated that on many occasions he has even received demands/invoices from radio station promoters he had never had contact with or even heard of.

Notwithstanding the various systems of payola in operation placing a new release, or potential release, on a radio station with good coverage was maintained by those interviewed as especially difficult and doubly difficult for songs from outside the US. In an interview Lynne Leger, Vice President of Retail Marketing for EMI Music Distribution (EMD), suggested that the recent restructuring of radio had greatly decreased the opportunities to get new music to the consumer. Furthermore, she echoed the complaint of other respondents that US radio does not support 'announce artists' (those artists just released or about to be released); meaning that it can take a long time for a single to become associated with an artiste's other products (albums, tours, etc.).

In addition to the above difficulties getting the right type of airplay to back a new product also depends on understanding a product's evolving geography. It is common for new artistes and genres to be tested on certain urban areas. For instance, Nashville has long been the first release and testing market for country music and European dance and alternative music has long been advance tested and released in New York and to a lesser extent Los Angeles and San Francisco. Breaking an artiste most often follows a particular geographic pattern that is first centered on what are considered by the industry to be a place where the largest number of the particular genre's early adapters live/shop. It is only after success on these markets that financing will be found for the 'diffusion' (Caves 2000, p.154) of the innovators' new found tastes. This has specific implications for the promotional efforts of the record companies. As the diffusion process continues they coordinate staggered releases of the product, appearances and performances, and crucially their attempts to influence radio play.

The initial testing process is often referred to by industry actors as 'creating a buzz' and it is common for both domestic and foreign record companies to turn to independent US record companies to help with this task. Danny Goldberg - CEO/coowner of Artemis Records and formerly CEO of Polygram-Mercury Records and Warner Brothers Records and President of Atlantic Records - said that it was not uncommon for independents, such as his, to receive several hundred thousand dollars from a major to "see if a buzz can be created" (from an interview conducted in October 2002). Other respondents suggested that it was generally accepted that at present US $\$ 500,000$ was required to 'test' a record. Such testing can take many forms 
depending on the product's genre but for rock and pop testing involves hiring a team to organize a targeted press campaign, a set of performances, and above all organizing/paying for airplay. In relatively rare circumstances independent record companies undertake this task in the hope of creating a hit and thereafter selling it themselves. More usually the initial testing is carried out by smaller, or independent, record companies that are either directly contracted by a major to carry out the work or pay for the testing themselves in the hope that the product will be taken on by a major, or be given a licensing deal, once the product's viability has been proven. In this way smaller firms in the US function in similar ways to IT and biotech firms that front load the risk inherent in product development themselves in the hope of raising further venture capital or successfully selling the company to either a larger concern or through a public offering.

Thus the initial testing or attempt to create a 'buzz' is most often merely a strategy to get a larger record company, or sometimes a distributor, to take an interest in the product/act and promise to fund a larger coordinated promotional and sales campaign. A larger campaign includes a wider variety of promotional techniques: including recording a video and organizing its airplay, traveling sales teams, tours and performances, a costly nationwide radio offensive, and (to be dealt with later) a budget for store level promotions. Officials at BMG, EMI, and Sony said that detailed studies of the costs of breaking and promoting an act are produced but these are highly sensitive documents and are not even widely shared within the organization itself. However, the industry actors interviewed said that such larger campaigns were estimated by to cost, for a pop or rock act, from a minimum of US\$2 million to a maximum of around US $\$ 10$ million. Respondents suggested that on average most Top 10 hits on the US charts were backed by a sales and promotions budget of around US\$5-6 million.

\section{Getting it into people's hands: labels and distribution}

Whilst heavy radio play is the core element of a promotional effort to break a record in the US this is of little use if the single or album is not readily available to consumers. Despite the fact that, as mentioned earlier, the internet and mobile telephony are having profound effects on the sale and distribution of music, at present music is still predominantly sold as a physical commodity - embedded as it is in a piece of plastic (IFPI (International Federation of the Phonographic Industries) 2004). As such it needs shipping, warehousing and distribution to retail outlets. A distribution deal usually allows the music to be reproduced in the US thus avoiding the tariffs and expenses incurred in importing large volumes of plastic and the extra costs of the product going through two distributors. Due to US law imports must pay mechanical royalties in the US even though these have already been paid in the country of origin: i.e. they pay double royalties. Such a deal is further necessitated by the de facto division - partly due to copyright laws and partly due to agreements between the major record companies - of the world's music market into a series of territories. This means that a US major will not distribute product from it's sister majors in other countries and vice versa. In practice then each national branch has control over what gets released, or not and pricing levels in its territory.

In general, one may say then that the two main reasons for why musicians and foreign music firms seek US distribution deals are the system of territories and the 
cost advantages of US manufactured products enjoy over imports. However, a third reason for the necessity of such deals, especially for a newly breaking product, lies with the structure of the US distribution market and the central role distribution firms play in placing products on the retail market in the right way and in the right place.

In the US, music gets distributed by companies that fall into one of three main categories: a major record company that owns its own distribution network; independents that are distributed by the distribution wing of a major; independents that distribute their product through independent distributors (i.e. those with no affiliation to a major). The first two categories dominate the US market: i.e. the majors. At present major-owned distributors are responsible for around $85 \%$ of the music distributed to retailers and wholesalers. Independent distributors' market presence has continually decreased during the last 30 years and today they are overwhelmingly involved in specialized and niche markets and in selling to the decreasing number of small independent retailers: though this is of course an important role (Passman 1997). Also the growth since the 1960s of rack retailers firms that organize the music sections/racks in mass merchandisers such as department stores and supermarkets which account for around $40 \%$ of US sales (NARM (National Association of Recording Merchandisers) 2001) - has further consolidated the distribution system in that large rack buyers will not deal with small firms or in small quantities.

All of the majors directly own distribution companies that are more or less vertically integrated into their operations. In fact, these distribution arms provide the parents with much of their profits, often employ far more people (Warner's distributor WEA employs three times as many as Warner Music itself), and are strategically important sales tools. It is widely considered that the primary reason that the majors built up such extensive and powerful distribution systems is that it has allowed them to ensure the complete integration of their promotional efforts with product stocks and releases in targeted areas. An extensive distribution system also makes them more flexible as they are capable of making available substantial extra units of records that 'come out of nowhere'. The firms are thus a blend of sales and marketing and physical distribution.

As mentioned above many independent record companies are also distributed by the majors owned distributors. This is mainly due to the costs associated with building up a nationwide warehousing and distribution system. It may also be due to the fact that US retailers pay for product in arrears and have traditionally been notoriously slow, even recalcitrant, in paying their bills. Legal costs and bridging costs associated with lax payment practices are often cited by independents as a key additional reason for outsourcing distribution. The bigger companies, however, can largely avoid the extremes of slow-payment due to their power to withhold large catalogues and the biggest stars from retailers (Caves 2000, p.158).

It is commonly said within record companies that distributors have no marketing power and are thus relatively powerless to do anything to help break an act (Music Business International 1997). Interviews with distributors and retailers suggested this not to be entirely true.

Firstly, the distributors have an effect on the price of the product. The larger the distributor the larger the economies of scale that apply to their operations: in particular in the areas of warehousing and shipping/logistics. Furthermore their control over the supply of the titles that sell the highest volumes means that they have the power to demand from retailers higher prices and lower discounts for the products they represent. This is important as music sales are, in general, highly price sensitive. 
Also the music business is one where traditionally high levels of 'discounting' apply. Discounting in the form of 'normal distributor free goods' means that major distributors give away around $15 \%$ of the units they ship. This practice is widely seen merely as a way of reducing royalty liability: companies only pay artistes royalties on goods that are sold to retailers (see Passman 1997). However, an additional 5-10\% of product shipped are often given away in the form 'special campaign free goods' which act as a powerful promotional tool commonly used in the early stages of breaking a new product. Thus the power of the distributor over price and 'discounting' levels have important effects both for the readiness of retailers to buy new titles and ultimately to the level of royalties that are returned to the musicians.

A related aspect of distributors' sales role is that they commonly engage in 'bundling': insisting that a buyer take one title in order to receive a second. As is common in other entertainment industries, such as film and television, music distributors often sell certain new releases as part of larger bundles. This ties retailers into accepting new products they might not otherwise risk ordering in significant levels. Though not as widespread as in the film industry bundles - especially discounted promotional bundles - are an important placement and pricing tool; though one that only the majors' distributors have the power to effectively use.

Secondly, research revealed that distributors act in many ways as key promoters of products. Whilst they have no direct contact with the record buying public they have direct and long-term relationships with the record stores' 'buyers'. The major distributors all employ large numbers of people engaged in sales and promotions. Interviews with WEA USA, for instance, revealed that they employ over 70 specialized retail marketing teams across the country. These teams mainly target particular regions. However, the big distributors also have offices and teams dedicated to particularly large buyers. WEA for example have teams in Minneapolis to serve the mass merchandiser Best Buy and in Arkansas serving Wal-Mart. Specialized sales and marketing teams allow the distributors to build close, long-term relationships with the retailers and wholesalers they sell to.

The main way in which distributors influence the promotion, or breaking, of a product is through their 'priority lists'. Every month a distributor receives a list of priority products (and associated sales and promotions budgets) from a label which is meant to guide the distributor's sales and promotions efforts. However, a large distributor that deals with many record labels will receive many such priority lists. Respondents pointed out that the distributors have considerable leeway in 'prioritizing the priorities'. Whilst this second level of prioritization is said to usually favor the products of the distributors' parent group this is not always the case. The distributors have the power to say no to a title and are after all profit seeking commercial firms that earn fees on per unit sales. In order to maximize these fees they conduct their own cycle of product profiling and assessment in order to ascertain which products it will prioritize and where sales and promotions budgets will be spend. Historically heads of distribution firms have also been extremely active in the labels' discussions over priorities and general group strategy. It is for these reasons that the executives of the major distribution companies are commonly thought of as some of the most influential figures in the US music industry.

Research revealed that it was widely assumed that the majors' distributors overwhelmingly favored American repertoire as this was easier to sell in large volumes and was more likely to be backed by the scale of radio campaign needed to drive hits. That the mainstream distribution system is almost completely focused on domestic product can be seen in the fact that even foreign branches of the majors are 
forced to use the less powerful independent distributors to distribute their products in the US. Interviews with the French and Swedish music export authorities and Swedish record companies revealed that acts already signed to a European branch of a major often turn to independent distributors in order to place their product on the US market. The links between US branches of the majors and European branches are not always smooth and evidence suggests that horizontal integration of operations can be lacking. Jean-Francois Michel, Director General of Bureau Export de la Musique Française, noted for instance that French branches of BMG and Universal have both had to use independent US distributors rather than those of their own company. However, he noted that Warner Music France and Sony Music France were generally not afforded such freedom from the corporate group with the result that historically they have had a much narrower range of their products available in the US. Christer Lundblad, head of Export Music Sweden, said Swedish/Scandinavian divisions of the majors were also either a low priority for their US counterpart or ended up using independent US distributors. Both Michel and Lundblad and respondents from Swedish branches of the majors said that their difficulties in accessing the majors' US distributors meant they were at a considerable disadvantage in unlocking the promotion and sales resources and networks needed to ensure both product availability and recognition.

\section{At the storefront: the power of retailers}

In addition to the difficulties involved in assuring good radio and distribution in the USA the nature of music's retail environment presents another level of both barriers/gatekeepers and huge expense for those interested in breaking new musical products.

The US retail market consists of a constantly changing balance between specialised retailers, rack retailers, mail order and on-line sellers. In 2000, specialised record stores accounted for $42 \%$ of the years total sales of musical products and related merchandise whilst mass merchandisers/rack retailers took $41 \%$, tape/record clubs $8 \%$, the internet $3 \%$ and the rest accounted for by various outlets such as TV shopping and mail order (NARM (National Association of Recording Merchandisers) 2001). Whilst very little of the popular music market is at present on-line this may change; estimates are that $70 \%$ of classical music is now sold on-line (Black 2002). Despite the continuing evolution of the balance between these different retail forms, the specialist music multiple/chain retailers remain especially important for the early career of both new artistes and the new products of established stars. When asked about the crucial difference between specialist retailers and other types of retailer Mike White - Executive Vice President and General Manager of Sales, Marketing and Operations WEA - said:

"Mass merchants [such as rack retailers] do not break artists. They sell hits." (From an interview conducted in October 2002)

In contrast, specialist stores are where new music first arrives and remain the focus, at least in America's urban areas, for music buyers' attentions. What they stock and advertise is taken note of and most importantly it in these stores that sales data for the charts are collected; stores that are chart data sources have a powerful role in the industry (McCourt and Rothenbuhler 1997). As such access to specialist music stores, 
and in particular the large speciality music chains (such as Tower Records, HMV, and Virgin), is a key priority for both labels and distributors interested in successfully breaking a product.

Accessing US specialist music retailers' stores is not however an easy or cost free process. In common with retailers in other sectors those selling music understand that different areas of a store attract customers' attention better and lead to higher sales volumes. In recent years a micro-geography of pricing and product placement has emerged in US music stores. Certain highly visible areas of a store such just inside the entrance, chart and recommendation walls, listening stands, end of aisle displays ('endcaps'), and well situated portable displays ('A-frames') almost guarantee dramatically higher sales volumes. Interviewees were of the opinion that whilst no exact figures could be quoted a generally accepted rule of thumb was that prominent new releases in key in-store locations sell 3-4 times the volume they would if merely placed in racks. For less well known or unbroken artistes this figure was said to be at least 15 times the normal sales volume.

In order to get their products in the desirable in-store locations retailers charge the record labels/distributor undisclosed sums: known as 'price-and-positioning' costs. Whilst the retailers interviewed would not comment on these charges executives from record companies and distributors interviewed said that the fees were a minimum of US\$1 per unit to about US\$1.50 per unit for the best locations in the stores with the highest turnover.

In addition to 'price-and-positioning', retailers charge record labels and distributors for advertising. Research revealed that retailers in New York City charge record companies between US\$5-10,000 to have a poster of a record cover in an individual store's window. Furthermore retailers universally demand what are known as 'cooperative advertising funds' to pay for television adverts, the retailers' own magazines/circulars, flyer and poster campaigns, etc. Through this the record labels effectively pay for the retailers' advertising. The costs of such advertising vary greatly between the retailers but respondents from both record companies and retailers agreed it can amount to tens of thousands per retailer per release.

All of these payments to retailers are in addition to the normal discounts and free goods retailers are provided with. In recent years retailers have begun to differentiate between seasons and it is now common practice to charge record companies $50-100 \%$ more than normal in the two months running up to Christmas: for both 'cooperative advertising' and 'price-and-positioning'.

Industry respondents said that payments to retailers for in-store visibility and the like commonly account for around a half of a release's total marketing budget. In the case of big releases this can amount to several million dollars.

"With the exception of independent radio promotion, price-and-positioning is the cost that senior label and distribution executives consider the most onerous in marketing music" (Christman 2002)

Label and distributor executives complained not only that these costs are spiraling but also about what they considered the poor store level execution of product placement they had paid for. They also complained that the cooperative advertising funds they provided were seldom spent and that such funds are used by retailers as a ready extra income source. Interviewees suggested that such expenses underlined the lack of interest in music many retailers now exhibit: 
"They like what you give them money for." (Interview with Mike White, Executive Vice President and General Manager of Sales, Marketing and Operations WEA, October 2002)

The power of retailers in the area of pricing also appears in more under-thecounter practices. In 2002 the government brought a lawsuit against the majors and certain of the largest retailers due to their practice of pricing-fixing. The lawsuit resulted in the majors and retailers agreeing to pay US\$143 million in compensation to consumers. Such price-fixing deals between the largest actors were also subject to earlier Federal Trade Commission investigations.

Finally, it is important to note in this context that the 'concrete' physical space (square footage) for retailing phonograms has decreased since many specialized music retailers have closed down. According to Kusek \& Leonard (2005) approximately 1200 US music retailers closed down between 2000 and 2003. One major factor influencing this structural shift is the fact that primary distributors (i.e. the 'majors') have shifted from traditional music retailers over to the 'big box' retailers such as Best Buy, Target, and Wal-Mart. Thus decreasing sales points and the enormous costs involved in placing products in existing stores weigh heavily even on the well financed majors. For relatively unknown or less popular artistes and for independent record labels the scale of these changes and costs represent significant barriers to entry into the US market.

\section{The Cadillac showroom: the focus on big hits in a shrinking market}

"Some economist had a theory of creative destruction. I see the destruction but right now I don't see the creation". (From an interview with Danny Goldberg, CEO/co-owner of Artemis Records, New York, October 2002)

Perhaps the most important difficulty foreign exports to the US music market face is the fact that the market has in the last few years been in crisis. Between the first half of 2001 and the first half of 2002 total US music shipments dropped 10\% (from 442.8 million units in to 398.1 million units) which represented a 7\% decrease in wholesale revenues: US $\$ 5.93$ billion in the first half of 2001 to US\$5.53 billion in the first half of 2002. A combination of factors are behind this downward trend: decreased consumer spending due to the recession; CD copying and internet piracy (Cooper and Harrison 2001; Leyshon 2001; Shirky 2001; IFPI (International Federation of the Phonographic Industries) 2001b; Alderman 2002; Alexander 2002); the end of the CD replacement market; and the growth of alternative home entertainment formats such as computer games and DVD (in 2002 the US DVD market was estimated at around US $\$ 20$ billion). In response to the shrinking market for music US retailers have begun to place greater emphasis on other more profitable merchandise: in particular DVDs and computer games. Mass merchandisers have already transferred much of the space once devoted to music to DVD. The large speciality music chains have begun dramatically cutting back on the range of music they carry and are sacrificing 'deep catalogue' (older or more specialised titles) for other entertainment products, principally DVD.

In addition to the shrinking market many of those in marketing and sales roles we spoke to suggested that the industry is facing a rapidly segmenting marketplace in which consumers have become 'unpredictable'. In this view consumers are no longer satisfied to enjoy exactly the same music as almost their entire global generation and 
therefore there is little time left for Elvis and Beatles type phenomena. Whilst there is little doubt that musical tastes appear to be ever more segmented and specialised a cursory look at the charts in any industrialized economy demonstrates that there is still a central role for the global super-hitters.

In the early 1990s when the music industry was awash with cash and therefore able to afford to finance large numbers of releases the problems and costs associated with breaking an act and consumers' changing tastes could be largely overlooked by music industry firms. Now that the market for the traditional products of the music industry - recorded music and related copyrights - is in decline the industry's bigger actors seem to be rapidly refocusing their energies and restructuring their operations. In particular, companies reported that they were attempting to develop new product lines such as on-line music and, in particular, CDs that had a high level of DVD content or high profile music DVDs. They have also begun to agree new forms of contract with artistes that allow the record companies to share in the artistes' potential touring, merchandising, advertising and film earnings. All those interviewed, both majors and independents, said that they have been forced to attempt to radically downsize their overheads and operating costs: e.g. by firing staff; closing regional and overseas offices (which has led to an increased concentration of the industry in New York City); and concentrating on the 'major territories'.

For the all important majors, and the largest independents, the current situation has meant that they are changing their corporate culture towards one that is solely focused on producing and promoting acts that they believe to be potential global superstars. This process can be most easily seen in the fact that these firms have all been busy reducing their existing rosters and signing less new acts. Given the shrinking market and the costs associated in breaking an act on the US market the firms main adjustment policy has been to concentrate on a greatly diminished number of priority products. For example, when interviewed Patrick Reilly - Vice President of Corporate Communications for BMG - said that BMG has reduced its global priority list from a mid-1990s level of around 25-30 to a present day level of 5-10 products. Several of these 5-10 he said will be new breaks but others will be drawn from 'deep catalogue': such as Elvis compilations. Not only are these priorities more limited in numbers they must also not have been broken significantly elsewhere: i.e. the corporations' US costs are so high that they need a product capable of being rolled out on global basis so that additional revenue from international rights and territories can fully cover the initial launch costs. This means that the US branches of the majors now have increased powers to determine the distribution of products in other markets (in particular Europe and Japan).

The type of products the majors are now focused upon has been dubbed by those working in the US industry as 'Cadillacs'. By this they mean already well established, mainstream, heavy and reliable sellers that have a long life expectancy. Executives from the independents that were interviewed suggested that this will mean a splintering of the US, and indeed global, music market with the majors focusing almost entirely on catalogue (which costs relatively little in marketing costs) and 'Cadillacs' and the independents left to develop and break new music and music with limited sales appeal. Interviewees suggested that the fact that the majors, and even some of the larger independents, were part of larger media concerns meant that they were particularly vulnerable to the difficult market for music. This was because the parent or corporate group would be assessing whether project capital now devoted to breaking pop and rock acts would not be better spent launching magazines, computer games or any one of the myriad products their group is involved in the production of. 
These types of market dynamics are widely seen in the industry to favour the more flexible independent US record companies who do not rely on the same economies of scale and have not the same overheads as the majors. In many ways then the music industry is undergoing a very similar restructuring process to the one many commentators have claimed has already occurred in the film industry (Christopherson and Storper 1986; Storper and Christopherson 1987; Christopherson and Storper 1989; Storper 1989; Scott 2002). If the current restructuring of the music industry continues to follow the example of the film industry then we can expect the majors to concentrate more and more on 'Cadillacs' thus leaving increased space for flexible and specialised independents to both develop and market their own products and to work with the majors through project based subcontracting and outsourcing. If such a shift occurs it may be beneficial to those wishing to export to the US as US independents have historically been more open to foreign repertoire. Spatially it seems likely that music will follow film with a similarly paradoxical process of simultaneous spatial consolidation and fragmentation. Just as in Hollywood, the majors will seek to continue to centralize their control and command functions in one place - particularly New York - and intense competition between smaller centres around the world will continue as they vie with each other to be the 'locations' for shooting and producing the next big thing.

\section{Conclusion}

Whilst the article has outlined four main barrier areas all respondents pointed to a cultural and knowledge gap between the US and the rest of the world as potentially the most insurmountable barrier to entry; insofar as this cultural and knowledge gap lay under all four. Aside from a different business culture and operational context most foreign musicians and music industry actors lack sufficient personal contact networks in the US. The music business is one where trust and personal relationships are central. It is increasingly rare these days in the USA to get a gatekeeper (be it a radio or label gatekeeper) to even listen to unsolicited material. Gatekeepers filter the enormous amount of music out there by only allowing in material that comes through trusted personal contacts. In relation to the US market it appears that five distinct tasks are crucial to placing a product: securing the support of a major financial backer (usually a major label) capable of supplying a marketing and sales budget; securing a good licensing or distribution deal; employing a well-connected sales and promotion team; securing/buying press and radio exposure; securing/buying good access to retailers. Each of these tasks represents something akin to a 'pipeline' (Bathelt, Malmberg and Maskell 2002) for products' entry into the market and has associated gatekeepers. However, the one must be careful with this metaphor as it perhaps suggests something more fixed and permanent than these connections really are: in reality they are constantly changing and being renegotiated. Despite the fact that these 'pipelines' are far from fixed they do seem to exist and therefore it seems imperative for potential exporters to tap into the networks of personal contact leading to gatekeepers. Whilst these gatekeepers apply aesthetic and taste based appraisals to all new products it appears that, like many things in life, money is the most effective way of accessing gatekeepers and the pipelines they control.

The contemporary combination of the scale of costs to break a product and the shrinking market means that the US industry will no doubt undergo further restructuring in the coming years. What is clear is that whilst the US market is 
difficult for domestic product it is many times more difficult for foreign product. In short, the costs and difficulties of entering the US market form powerful barriers to entry. National governments or industries could help their music industries through the provision of greater support to exporters interested in the US market: as the French have done with their Music Offices and the British have been discussing (D'Arcy and Brindley 2002; Power 2003). In time such measures may improve foreign repertoires' success in America but for the moment many of the largest foreign artistes are in fact their backs on America and concentrating on getting big elsewhere. This bodes badly for the likelihood that in the near future America's export success and cultural influence may be better balanced by a more open market to its foreign competitors. Moreover a key finding of this article is that at present the size and cost structure of the US market not only produces barriers of entry to the US market but also makes it imperative that globalised music firms recoup their US costs through prioritizing US products abroad. In short the dominance of US repertoire on world markets is more to do with commercialization costs in certain markets than it is to do with cultural imperialism.

The structures and dynamics reported on above have important implications for economic geography and for those interested in the development of music industry competitiveness at a regional level. Throughout the research no one ever questioned the fact that excellent musical products were produced outside the USA. Rather it was the structure of the US market, conditions of access, and gatekeepers to key activity areas that were pointed to as the reason why foreign products occupy such a small place in the market. This demonstrates that, at least in the case of musical products, one cannot assign analytical priority to the dynamics (clustered or not) involved in producing and developing advanced, innovative or first-rate products. The manufacture or recording of musical products should be considered only a first step in the commodification and commercialization processes that largely determine their success. In these processes it is often at the level of marketing, distribution and retail that success is best assured. This implies that power over the commercial success of export-oriented products is largely 'located' outside the local milieu or center where production takes place. In conclusion, the contention in this paper has been that if we are to understand success or failure in music sales and better develop regional production milieus we must not only focus on the ideas of local production and innovation centers. We must also attempt to understand the actors and processes by which structure the marketing, distribution and retail of products in different markets. Thus whilst the geography of production and innovation is vital to industrial success it can only ever be part of what is often a much more complex story.

\section{References}

Alderman, J. (2002). Sonic boom : Napster, MP3 and the new pioneers of music. London, Fourth Estate.

Alexander, P. (1996). "Entry barriers, release behaviour, and multi-product firms in the popular music recording industry." Review of Industrial Organization 9: 85-98.

Alexander, P. J. (1996). "Entropy and popular culture: Product diversity in the popular music recording industry." American Sociological Review 61(1): 171-174.

Alexander, P. J. (2002). "Peer-to-peer file sharing: The case of the music recording industry." Review of Industrial Organization 20(2): 151-161.

Andersen, B., Z. Kozul-Wright and R. Kozul-Wright (2000). Copyrights, Competition and Development: The Case of the Music Industry. Geneva, UNCTAD Discussion Paper 145.

Amin, A., Thrift, N. (1992) Neo-Marshallian Nodes in Global Networks. International Journal of Urban and Regional Research 16, 571-587. 
Amin, A. \& Thrift, N. (1994): Living in the global. In Amin A. and Thrift N. (eds.) Globalization, institutions, and regional development in Europe, 1-22. Oxford University Press: Oxford.

Bathelt, H., A. Malmberg and P. Maskell (2002). Clusters and Knowledge: Local buzz, global pipelines and the process of knowledge creation. Second International Symposium on "knowledge and Space", Heidelberg.

Bathelt, H., A. Malmberg and P. Maskell (2002). "Clusters and Knowledge: Local Buzz, Global Pipelines and the Process of Knowledge Creation." DRUID Working Paper 2002-12. Copenhagen.

Black, J. (2002). A Rhapsody in Green for Classic Fare? Business Week. August 12.

Burnett, R. (1996). The Global Jukebox: The International Music Industry. London, Routledge.

Camagni, R. 1991. Introduction: from the local 'milieu' to innovation through cooperation networks, in Camagni, R. (ed.), Innovation Networks. Spatial Perspectives. London, GREMI-Belhaven.

Caves, R. (2000). Creative Industries: contracts between art and commerce. Cambridge, Mass., Harvard University Press.

Choi, C. J. and B. Hilton (1995). Globalization, Originality, and Convergence in the Entertainment Industry. Advances in Applied Business Strategy. L. Foster. Greenwich, CT, JAI Press.

Christman, E. (2002). "Holiday retail programs irk labels." Billboard 114(39).

Christopherson, S. and M. Storper (1986). "The City as Studio - the World as Back Lot - the Impact of Vertical Disintegration on the Location of the Motion-Picture Industry." Environment and Planning D-Society \& Space 4(3): 305-320.

Christopherson, S. and M. Storper (1989). "The Effects of Flexible Specialization on Industrial-Politics and the Labor-Market - the Motion-Picture Industry." Industrial \& Labor Relations Review 42(3): 331-347.

Clark, G. (1998). "Stylised Facts and Close Dialogue: Methodology in Economic Geography." Annals of the Association of American Geographers 88(1): 73-87.

Cooke, P. and Morgan, K. (1998) The associational economy. Blackwell, Oxford.

Cooper, J. and D. M. Harrison (2001). "The social organization of audio piracy on the Internet." Media Culture \& Society 23(1): 71-+.

Dannen, F. (1991). Hit men : power brokers and fast money inside the music business. London, Vintage.

D'Arcy, D. and P. Brindley (2002). Make or Break: Supporting UK music in the USA. London, British Council.

Denisoff, R. S. and W. L. Schurk (1986). Tarnished gold : the record industry revisited. New Brunswick, N.J ; Oxford, Transaction Publishers.

duGay, P. and K. Negus (1994). "The changing sites of sound: music retailing and the composition of consumers." Media, Culture and Society 16: 395-413.

Dicken, P. 1992 Global shift: the internationalization of economic activity. London, Chapman.

DuNoyer, P. (2002). Liverpool: Wondrous Place: Music from Cavern to Cream. London, Virgin Books.

Eliot, M. (1990). Rockonomics : the money behind the music. London, Omnibus.

Federal Communications Commission (2001). Review of the Radio Industry, 2001. Washington DC, Federal Communications Commission, Mass Media Bureau, Policy and Rules Division.

Firth, S. (1992). The industrialisation of popular music. Popular Music and Communication. J. Lull. Newbury Park, CA, Sage.

Gereffi, G. (1994). The organization of buyer-driven global commodity chains: how US retailers shape overseas production networks. Commodity Chains an Global Capitalism. G. Gereffi and M. Korzeniewicz. Westport, Conn., Praeger.

Gereffi, G. and M. Korzeniewicz, Eds. (1994). Commodity Chains and Global Capitalism. London, Praeger.

Hallencreutz, D. (2002). Populärmusik, Kluster och Industriell Konurrenskraft. En Ekonomiskgeografisk Studie av Svensk Musikindustri. Geografiska regionstudier, 47, Uppsala: Kulturgeografiska institutionen, Uppsala universitet.

Hallencreutz, D., Lundequist, P. och Malmberg, A. (2000). Production of popular music: on the industrial geography of the Swedish music cluster. Nordisk Samhällsgeografisk Tidskrift, 30, 37-59.

Hallencreutz, D., Lundequist, P. och Malmberg, A. (2003). Local embeddedness and international competitiveness: the case of the Swedish music cluster. In A. Amin, S. Goglio and F. Sforzi (eds.) The institutions of local development. London, Ashgate. 
Hallencreutz, D., Lundequist, P. och Malmberg, A. (2004). Populärmusik från Svedala. Näringspolitiska lärdomar av det svenska musikklustrets framgångar. Stockholm, SNS Förlag.

Hesmondhalgh, D. (1996). "Flexibility, post-Fordism and the music industries." Media, Culture and Society 18: 469-488.

Hirsch, P. (1992). "Globalization of Mass Media Ownership." Communication Research 19 (6: Special issue).

Håkansson, H. (1989). Corporate technological behaviour: co-operation and networks. London, Routledge.

IFPI (International Federation of the Phonographic Industries) (2001). The Recording Industry in Numbers 2001. London, IFPI.

IFPI (International Federation of the Phonographic Industries) (2001b). IFPI Music Piracy Report June 2001. London, IFPI.

IFPI (International Federation of the Phonographic Industries) (2004). The Recording Industry In Numbers 2004. London, IFPI.

$\mathrm{Ku}, \mathrm{R}$. S. R. (2002). "The creative destruction of copyright: Napster and the new economics of digital technology." University of Chicago Law Review 69(1): 263-324.

Kusek, D. \& Leonard, G. (2005). The Future of Music. Boston, Berklee Press.

Leyshon, A. (2001). "Time - space (and digital) compression: software formats, musical networks, and the reorganisation of the music industry." Environment and Planning A 33: 49-77.

Leyshon, A. (2003). "Scary Monsters? software formats, peer-to-peer networks and the spectre of the gift." Environment and Planning D: Society and Space 21(5): 533 - 558.

Leyshon, A., P. Webb, S. French, N. Thrift and L. Crewe (2005). "On the reproduction of the musical economy after the Internet." Media, Culture \& Society 27: 177-209.

Lopes, P. (1992). "Innovation and diversity in the popular music industry, 1969-1990." American Sociological Review 57: 56-71.

Maillat, D. (1991) The innovation process and the role of the milieu, in Bergman, E. M., Maier, G. and Tödtling, F., Regions considered. Economic networks, innovation and local development in industrialized countries. London, Mansell.

Mailat D. (1995) Territorial dynamic, innovative milieus and regional policy, Entrepreneurship and Regional Development, 7: 157-165.

Malm, K. and R. Wallis (1992). Media Policy and Music Activity. London, Routledge.

Malmberg, A. and D. Power (2005 Forthcoming). True Clusters / A Severe Case of Conceptual Headache. Clusters in Regional Development. B. Asheim, P. Cooke and R. Martin. London, Routledge.

McCourt, T. and E. Rothenbuhler (1997). "SoundScan and the consolidation of control in the popular music industry." Media Culture \& Society 19(2): 201-\&.

Music Business International (1997). Distribution: Power source or irrelevance? Music Business International. 7: 11.

NARM (National Association of Recording Merchandisers) (2001). 2000 Annual Survey Results: Figures reported for the 2000 business year. Marlton, NJ, NARM.

Negus, K. (1996). Popular Music in Theory: an introduction. Cambridge, Polity Press.

Negus, K. (1999). Music Genres and Corporate Cultures. London, Routledge.

Passman, D. (1997). All You Need to Know About the Music Business. New York, Simon \& Schuster.

Porter, M. E. (1990) The competitive advantage of nations. London and Basingstoke, MacMillan.

Porter, M. E. (1998) Clusters and the new economics of competition, Harvard Business Rewiew, NovDec: $77-90$.

Power, D. (2003). Final Report: Behind the music - Profiting from Sound: A Systems Approach to the Dynamics of Nordic Music Industry. Oslo, Nordic Industrial Fund - Centre for Innovation and Commercial Development.

Power, D. and Hallencreutz, D. (2002) Profiting from creativity The music industry in Stockholm, Sweden and Kingston, Jamaica. Environment and Planning (A) 34 (10): 1833-54.

Power, D. and Hallencreutz, D. (2005) Cultural industry cluster-building in Sweden. In Oinas, P. and Lagendijk, A. (eds.), Proximity, distance and diversity: Issues on economic interaction and local development. London: Ashgate.

Power, D. and J. Jansson (2004). "The emergence of a post-industrial music economy? Music and ICT synergies in Stockholm, Sweden." Geoforum 35(4): 425-439.

Power, D. and Scott A. J. (2004). Cultural industries and the production of culture. London, Routledge. 
Sadler, D. (1997). "The global music business as an information industry: reinterpreting economies of culture." Environment and Planning A 29: 1919-1936.

Saxenian, A. (1994) Regional Advantage. Culture and Competition in Silicon Valley and Route 128. Harvard University Press, Cambridge, Mass. and London.

Schoenberger, E. (1991). "The Corporate Interview as a Research Method in Economic Geography." Professional Geographer 43(2): 180-189.

Scott, A. (1999a). "The US recorded music industry: on the relations between organization, location, and creativity in the cultural economy." Environment and Planning A 31: 1965-1984.

Scott, A. (1999b). "The cultural economy: geography and the creative field." Media, Culture and Society 21: 807-817.

Scott, A. (2000b). The Cultural Economy of Cities: essays on the geography of image-producing industries. London, Sage.

Scott, A. J. (2002). "A new map of Hollywood: The production and distribution of American motion pictures." Regional Studies 36(9): 957-975.

Segrave, K. (1994). Payola in the music industry : a history, 1880-1991. Jefferson, N.C ; London, McFarland.

Shapiro, D., N. Abercrombie, S. Lash and C. Lury (1992). Flexible specialisation in the cultural industries. Regional Development and Contemporary Industrial Response. H. Ernste and V. Meier. London, Belhaven.

Shirky, C. (2001). "Sonic boom: MP3, Napster, and the new pioneers of music." Harvard Business Review 79(2): 143-148.

Storper, M. (1989). "The Transition to Flexible Specialization in the United-States Film Industry External Economies, the Division of Labor, and the Crossing of Industrial Divides." Cambridge Journal of Economics 13(2): 273-305.

Storper, M. (1995) The resurgence of regional economies, ten years later: the region as a nexus of untraded interdependencies. European Urban and Regional Studies, 2: 191-221.

Storper, M. and S. Christopherson (1987). "Flexible Specialization and Regional Industrial Agglomerations - the Case of the United-States Motion-Picture Industry." Annals of the Association of American Geographers 77(1): 104-117.

Storper, M. and A. Venables (2002). Buzz: the economic force of the city. DRUID Summer Conference on 'Industrial Dynamics of the New and Old Economy - who is embracing whom?' Copenhagen/Elsinore.

Sölvell, Ö., Zander, I. and Porter, M.E. (1991) Advantage Sweden. Stockholm, Norstedts.

Wallis, R. and K. Malm (1984). Big Sounds from Small Peoples: The Music Industry in Small Countries. London, Constable. 